\begin{tabular}{ccc}
\hline International Journal of Engineering \& Technology, $7(3.15)(2018) 267-272$ \\
SPC & Website w ww.sciencepubco.com/index.php/IJET \\
Research paper & Technology \\
\hline
\end{tabular}

\title{
Innovative Mechanisms to Counteract Risks and Threats to Foreign Economic Security of the Region
}

\author{
Tatyana Anatolievna Kulagovskaya1, Anna Alexandrovna Ter-Grigoryants1, Natalia Vladimirovna Maslennikova1, \\ Evgenia Nikolaevna Kovtun1, Lyudmila Vladimirovna Slavnetskova2
}

1North Caucasus Federal University, Pushkin St., 1, Stavropol, Russian Federation, 355009

2 Yuri Gagarin State Technical University of Saratov, Politechnicheskaya St., 77, Saratov, Russian Federation, 410054

\begin{abstract}
The article assesses the impact of internal and external factors on the economic security of the region in foreign trade activities. Negative consequences of the foreign economic activities on economic security of the Stavropol Territory are analyzed. Types of the risks enterprises may face when entering the foreign market are considered. Protectionist arguments in favor of pursuing a free trade policy are presented and argued, which implies a staged formation of a mechanism to efficiently counteract threats to the external economic security of the region.

The study considers the level and dynamics of the main macroeconomic indicators of the subjects of the North Caucasus Federal District as compared to the average Russian achievements, the resource potential, problems of the economic development of the macroregion, prerequisites for the formation of the state policy on supporting the region. It substantiates the top priority directions of long-term socioeconomic development of subjects in order to overcome the pervasive arrearage of the economy and social area.
\end{abstract}

Keywords: economic security, export, foreign economic activities, free trade, import, protectionism, risk management system, risks in foreign economic activities.

\section{Introduction}

The current conditions and dominating trends in the development of the global economy have created the situation when the competitiveness of regions and the achievement of strategic goals are determined by the results of economic entities' operation in the industrial sector. Crisis phenomena in the regions of Russia are caused by a number of factors that are specific for the territorial economic space. It is necessary to qualify some of them as prolonged, i.e. they continue to operate for a long time and go beyond transformational processes. Such long-term factors restrain the evolutionary process in the regional economy and deform its most important parameters, which contributes to a long-term recovery from the crisis, turns these factors into dominant ones, and implements more negative scenarios to resolve the accumulated contradictions [1].

In addition, due to the introduction of anti-Russian economic sanctions, reduction in the state budget revenues, decrease in world energy prices, an endogenous approach is implemented in managing the regional industrial development. This causes the need to analyze the industrial development of the macroregion and to define possible sources and technologies for ensuring industrial growth.

\section{Study Objective}

In the context of liberalization in the foreign economic activity of the country and its regions, there are new threats arising in relation to the national economic security or on the way to meeting economic needs, or that are dangerous for foreign trade participants.

The most important economic threat to security is the incapability of enterprises in terms of self-preservation and development, the weakness of the innovation factor, the inefficiency of the management system, etc. Thus, the problems of national enterprises associated with the inability to meet the domestic demand contribute to increasing the dependence of the economy on imported products and the world market, especially food products, machinery and equipment, international loans, deepening of the commodity orientation in export supplies.

\section{Results}

Every business entity plays an important role in any state. Doing business involves a number of problems and risks that, as a rule, are mostly created by the state. Today in the world there are many international economic organizations that can support sustainable development of an enterprise or provoke crisis phenomena.

According to the World Bank, the rating of countries (Doing Business) was compiled. It aimed at determining the rank (position) of each country in accordance with the sufficiency (necessity) of state support for business (Fig.1).

The most crisis years in the Russian economy were 2008 and 2014 As a result of the first world crisis in 2008, Russia had held position 120 in the World Bank rating. By 2014 the situation had improved, and Russia held position 62. In spite of the crisis phenomena, the state support for business remains unchanged, and, on the contrary, it is gaining pace. It is proved by the fact that Russia took position 30 in the new 2017 Doing Business rating. [2]. The position of the Russian Federation was improved in the rating due 
to such factors as improvement of the financial and credit policy, reduction of the tax burden, unification of state standards that

caused technical regulations, etc.

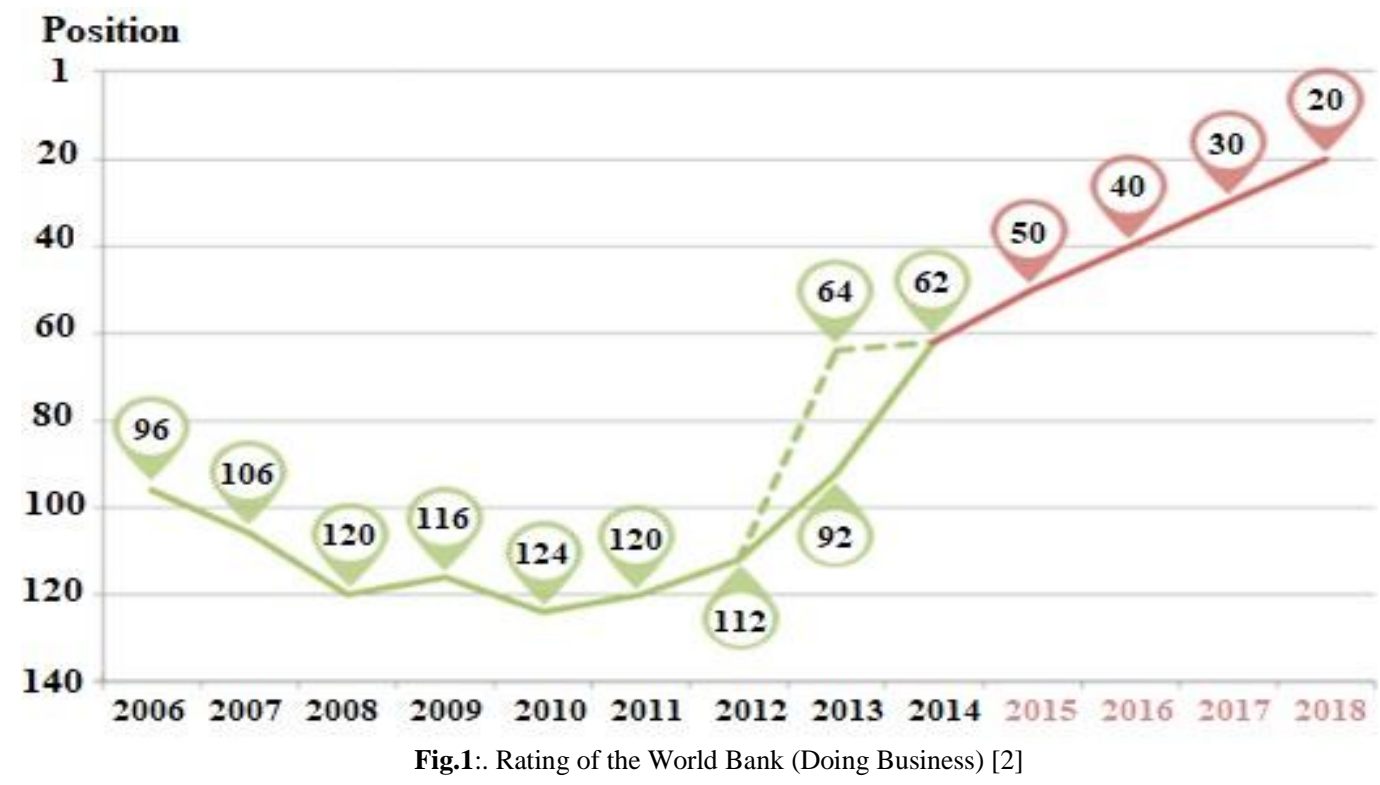

For promoting risk management, it is necessary to develop a risk management program aimed at developing mechanisms based on the world experience, methods and instruments of managing interstate and intrafirm levels. This program provides terms and conditions for rational decision-making, continuous risks' assessment, determining the significance and level of the risks' impact on important management decisions, and implementing a strategy to challenge risks at the regional level.

The process of managing elements of a risk management system is an auxiliary instrument for obtaining information that may be required for the risk management mechanism under development. Unfavorable trends should be analyzed, and their impact on this mechanism should be assessed. It is important that this mechanism makes it possible to reevaluate the identified risks that have systematic impact on the enterprise operation.

Thus, for efficient risk management of the enterprise, it is necessary to have an integrated risk management system that implies a comprehensive approach to assessing the maximum number of risk factors of the enterprise operating in the dynamic economic environment.

In accordance with this, the terms and conditions for doing business in Russia have been improved, which gives more confidence when new or existing enterprises enter the foreign market. To achieve the goal set in the "2017 May decrees" and related to position 20 as occupied by Russia in the 2018 Doing Business ranking, it is necessary, first of all, to improve customs regulation and obtain permits for establishing new enterprises.

Enterprises operating on the world market are the most vulnerable to environmental factors. Most of the risks will be associated with dishonest counterparties, the accuracy of the selected terms and conditions of supplies according to INCOTERMS, a low degree of the consumer market research, which will reduce the probability of their occurrence and, possibly, minimize damage (Table 1) [3].

Table 1:. Standard Types of Risks Enterprise May Face When Entering a Foreign Market

\begin{tabular}{|c|c|c|}
\hline In production & Risk & In trading \\
\hline Quality-to-price ratio & \multirow[t]{2}{*}{ Market (sales) } & Decrease in the demand or prices on world markets \\
\hline Consequences: overpayment for low quality products & & Consequences: profit reduction for the enterprise \\
\hline Purchases are not financed & \multirow[t]{2}{*}{ Commercial } & Buyer's inability to pay \\
\hline Consequences: shortage of materials for production & & Consequences: the enterprise does not have a profit \\
\hline No crediting without ready products or collateral & \multirow[t]{2}{*}{ Financial } & $\begin{array}{l}\text { Currencies' rate fluctuation, increase in interest rates for loans and } \\
\text { credits, differences in inflation tempos }\end{array}$ \\
\hline $\begin{array}{l}\text { Consequences: shortage of finances to purchase materials } \\
\text { and raw materials }\end{array}$ & & Consequences: insufficiency of state support \\
\hline Production monopolization & \multirow[t]{2}{*}{ Political } & $\begin{array}{l}\text { Change of the social and political situation and economic policy of } \\
\text { the foreign trade participants }\end{array}$ \\
\hline Consequences: prohibition on purchasing components & & Consequences: prohibition on selling products \\
\hline Decrease in production capacities & \multirow[t]{2}{*}{ Production } & Loss of a part of the market segment \\
\hline Consequences: Decrease in production volumes & & Consequences: Nonrational strategy of selling goods \\
\hline Supplies logistics & \multirow[t]{2}{*}{ Transportation } & Changes in the INCOTERMS terms and conditions of supplies \\
\hline $\begin{array}{l}\text { Consequences: nonrationalization of production process- } \\
\text { es }\end{array}$ & & Consequences: increase in expenses for transporting ready products \\
\hline Out-of-date technologies & \multirow{2}{*}{$\begin{array}{l}\text { Research and tech- } \\
\text { nical }\end{array}$} & Lack of technological and license requirements \\
\hline $\begin{array}{l}\text { Consequences: products that do not meet consumers' } \\
\text { needs }\end{array}$ & & $\begin{array}{l}\text { Consequences: increase in the cost of products and decrease in } \\
\text { quality }\end{array}$ \\
\hline No opportunity to use accepted transactions & \multirow[t]{2}{*}{ Accept risks } & Change of the method of paying for the foreign trade contract \\
\hline Consequences: change of the production cycle & & Consequences: prolongation of fulfilling contractual obligations \\
\hline $\begin{array}{l}\text { Low level of raw materials and materials' quality, suppli- } \\
\text { ers that are unequally distant }\end{array}$ & \multirow[t]{2}{*}{ Competition risks } & Competitors with products of higher quality at a lower price \\
\hline $\begin{array}{l}\text { Consequences: loss of loyal consumers and profit reduc- } \\
\text { tion }\end{array}$ & & $\begin{array}{l}\text { Consequences: reduction of the market share or change of the mar- } \\
\text { ket segment }\end{array}$ \\
\hline
\end{tabular}


The risk management program under development should aim at efficient and continuous management. Thus, early and continuous identification and assessment of risks is a guarantee of both economic and political security. Its creation should be associated with the formation of information reporting on all types of risks. Planning measures to reduce and prevent changes of external and internal conditions will at the same time have positive impact on the program itself and the development of the region, as a whole.

This risk management system should perform functions on identifying risks and their stable monitoring. To implement this, it is necessary to have a plan that includes a set of normative documents developed for certain areas of activity. This plan should adhere to the principles that are responsible for the specialization and time interval. The plan quality and systematization have impact on implementing all areas of the enterprise activity, and the coherence of the work of all enterprise units in the risk management system can ensure the efficiency of work on the foreign market.

It is necessary to note that the fall of prices for exported products or their growth for imported products, the introduction of such instrument as embargo on trading with countries or a group of countries that are considered to be the most important sales markets, or suppliers of products are also dangerous for the economy. The inadmissibility of high dependence on the supply of certain types of products from one country or a group of countries allows many countries to use this dependence, and creditors - to apply economic policy and impose terms and conditions of foreign economic relations.

Threats to economic security in relation to foreign trade activities are based on external and internal factors (Fig.2).

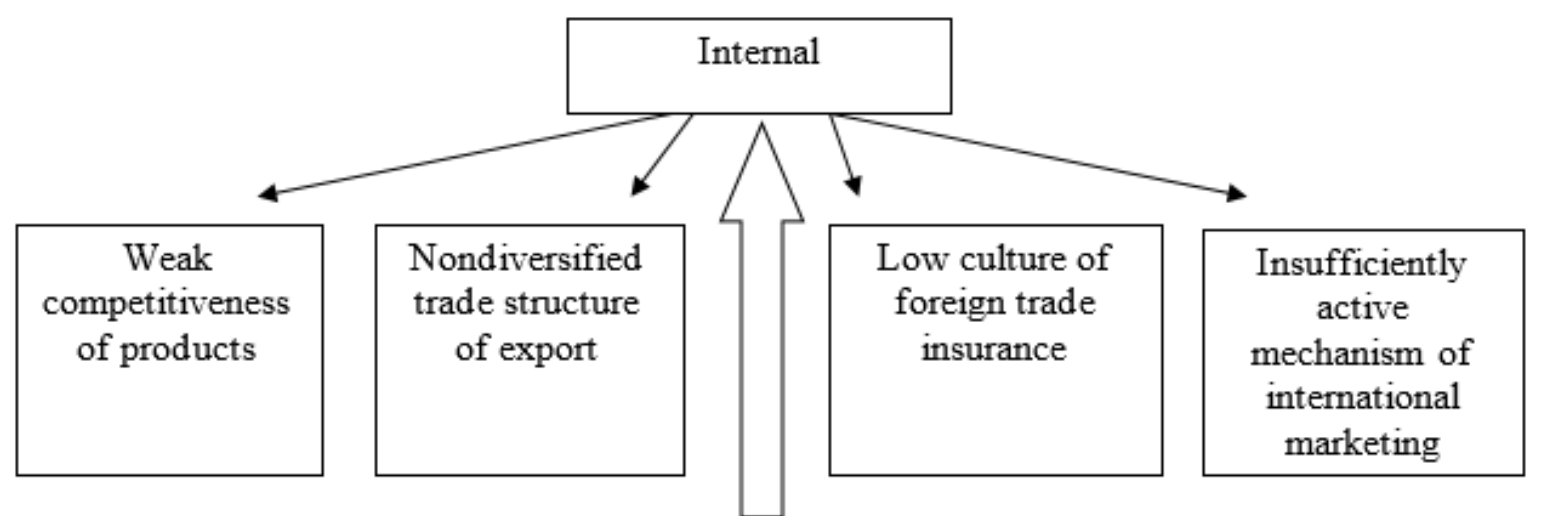

PROBLEMS CONSTRAINING FOREIGN TRADE DEVELOPMENT IN REGIONS

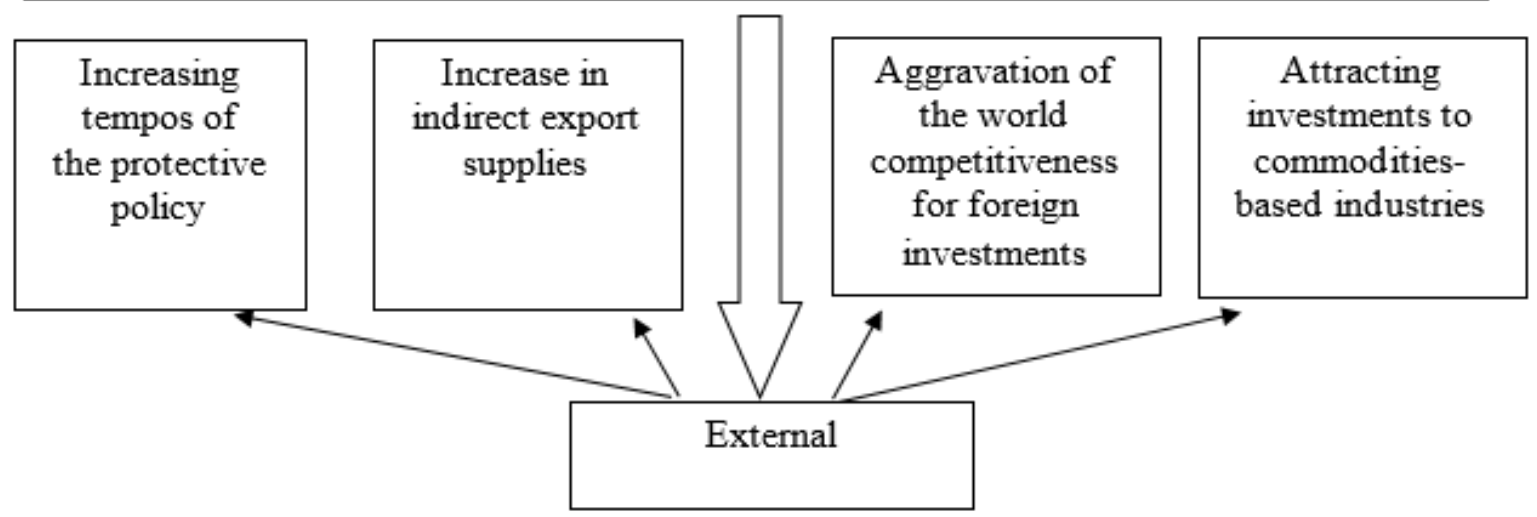

Fig.2:. Constraining Factors in the Development of Foreign Trade in Regions

It is possible to specify the following internal problems that cause threats: the limited nature of risk insurance opportunities, the lack of a technological mechanism for the interaction among professional market participants, etc. Now countries and regions face external threats. It is possible to single out the following ones:

- Strengthening of transnational cooperation, integration of national financial markets, internationalization of the world economy,

- Weakness in regulating the world financial markets subject to increasing volumes and turnover of operations, increasing competition among them,

- Increase in the global inconsistency due to entering of developing countries into the world economy,

- Constant growth of capitals that create tense environment and concentration of financial resources at the macroeconomic level,

- Growth of automation of transnational corporations and transnational banks that have a huge financial power, increased influence of some countries on national economic complexes,
- Intensification of financial transactions, increase in the mobility and interrelation of financial resources taking into account the latest information technologies,

- The interpenetrating role of the national and foreign policy of the country, increasing dependence on the world finances,

- Increased competition between Russia and other states in economic and other areas,

- Causing damage to the Russian exports by applying unreasonable discriminatory measures, and

- Overwhelming dependence of national economies on foreign short-term speculative capital that makes their financial systems extremely vulnerable.

The most important component of ensuring economic security in foreign trade is the study of threats that have impact on its dynamic processes and assessment of the degree of their impact.

It is necessary to define the following threats to the economic security of the Stavropol Territory in the foreign trade: reduction of the foreign trade turnover, strengthening of the impact of foreign policy conditions, and lowering of prices for raw materials. 
Foreign economic activities are important in the economic development of the Stavropol Territory. Today the Stavropol Territory trades with 100 countries around the world, most actively - with China, Azerbaijan, the United States, Turkey, Brazil, Germany, India, Italy and Korea, which account for $60 \%$ of the total regional foreign trade turnover.

As compared to the average Russian indicators, foreign trade in the Territory is not developed enough, but there are objective reasons for this: the basis of the Russian export is oil, gas and nonferrous metals. These are the products that are uncharacteristic of the Stavropol economy. The main export products here are those of the chemical industry [4].
According to Figure 1, in 2017 the import volume of foreign trade of the Territory's enterprises amounted to USD $775.52 \mathrm{mln}$. and increased by $12.84 \%$ as compared to 2016 . Goods for USD 671.59 mln. were imported from non-CIS countries (an increase by $17.04 \%$ ), and for USD $103.93 \mathrm{mln}$. (a decrease by $8.40 \%$ ) - from CIS countries.

The volume of export of Stavropol products to China increased by $52 \%$ in the first half of 2017 as compared to the same period of the previous year and amounted to USD $28.8 \mathrm{mln}$. TASS reported about this to the Ministry of Economic Development of the Stavropol Territory (Table 2) [5].

Table 2:. Dynamics of Main Indicators of Foreign Trade in the Stavropol Territory for 2016-2017 (USD, mln.) [5]

\begin{tabular}{|c|c|c|c|c|c|c|c|}
\hline \multirow{2}{*}{ Country type } & \multicolumn{2}{|c|}{2016} & \multirow{2}{*}{ Total } & \multicolumn{2}{|c|}{2017} & \multirow{2}{*}{ Total 2017 } & \\
\cline { 2 - 3 } \cline { 5 - 6 } & Import & Export & 2016 & Import & Export & \\
\hline Non-CIS countries & 573.79 & 737.89 & $1,311.68$ & 671.59 & 716.48 & $1,388.07$ & 445.84 \\
\hline CIS & 113.47 & 266.50 & 379.98 & 103.93 & 341.90 & $105.82 \%$ \\
\hline Total & 687.26 & $1,004.39$ & $1,691.66$ & 775.52 & $1,058.38$ & $1,833.90$ & $117.33 \%$ \\
\hline
\end{tabular}

In 2017 machinery and equipment for USD $361.87 \mathrm{mln}$. were imported to the region. This was $46.66 \%$ of the import value in 2017, including USD $349.36 \mathrm{mln}$. from non-CIS countries, and USD $12.51 \mathrm{mln}$. from CIS countries. As for machine-building products, it is possible to specify high cost volumes related to boilers, equipment and mechanical devices, and their parts. Their cost volumes in the reporting period amounted to USD 249.36 mln., or $32.15 \%$ of the value of import mainly supplied from such countries as Korea (Republic), China, Germany, the Netherlands, France, Italy and Turkey.

In the reporting period foreign trade participants of the Territory imported food products and raw materials for the amount of USD $123.44 \mathrm{mln}$., or $15.92 \%$ of the import value. The volume of these products' import has decreased by $6.48 \%$ as compared to the relevant period of the previous year.

In total, $26.11 \%$ of the import value is secured by the import of products from China, 9.12\% - from Korea (Republic), 6.90\% from Germany, and 5.98\% - from Ukraine. China was a supplier of bicycles, sport equipment, meters, tires and treads for cars and various equipment, Korea (Republic) supplied various mechanical and electrical equipment, Germany - various equipment and medical devices, and Ukraine - electric accumulators, building materials, wallpaper, rolled iron and iron rods.

During the whole period under study, a negative trade balance was noted in such industries as mineral products, machinery, equipment and vehicles, textiles, metals, and precious stones. The positive trade balance was formed, first of all, by exporting products of the chemical industry.

The growth of imports is good in case of structural reorganization and modernization of developed and some developing countries, but for the Stavropol Territory it is really dangerous. Threats from the influx of import stop the development of many sectors of economy, both in the Stavropol Territory and in neighboring regions. Capital inflows to noncompetitive enterprises stop. The engineering industry is affected. Incentives for national R\&D and innovations are torn down and conserve the technological arrearage of the construction and engineering base of the industry, including strategic sectors.

Economic specialists note the extensive nature of sectoral investments, their weak technological base and dependence on the world markets.

The share of manufacturing products in the structure of export is not more than $45 \%$ and is close to the lowest threshold value. This characterizes the Stavropol Territory as a raw material region.

The key industries in the export supplies of the Stavropol Territory are the chemical industry $(67.8 \%)$ and food products and agricultural raw materials $(21.4 \%)$. The dependence of export of mineral fertilizers on the main buyer - the United States, its share being $19.3 \%$, is of special danger.
The share of export of the region's high technology products on foreign markets (below 3\%) is below the threshold minimum (10$15 \%$ ), which points to a considerable technological arrearage of the region. According to many researchers and the experience of developed countries, such commodity structure of export puts the economy in jeopardy.

The share of import operations of the Stavropol Territory in the total volume of Russian import was $0.26 \%$. They are peculiar of a high share of cars, equipment and vehicles in the list of the imported goods $(33.5 \%)$. The cost volume of these products has decreased by $5 \%$ as compared to the previous year, and the structural content of this commodity group has changed.

Previously, in the import of machinery and technical products, the main volume of supplies fell to machinery and equipment for industrial purposes, i.e. investment goods intended for the technical reequipment of enterprises of the national industry. Today nonproduction goods (consumer electronics and electrotechnics, cars and others, i.e. consumer products) dominate in the import of this group.

Products of a rather high degree of processing prevail: oil and gas steel pipes, and cold-rolled sheet steel for the automobile industry prevail in the import of ferrous metallurgy products.

Large gaps in the import of goods can be observed in processing industries and import of goods produced by extractive industries. This fact is not negative for the region. In fact, there is nothing surprising in the fact that the Stavropol Territory imports a lot of machinery, equipment, vehicles and other products of the processing industry. However, under the current circumstances, this gap as a whole has the adverse impact on the national economy. It is explained by the fact that the import of machinery and equipment is compensated by the supplies of fuel and raw materials, the reserves of which are limited and that are extracted mainly in hard-to-reach regions of the country.

The import has been recently aimed at meeting the current consumer needs. Its investment component has decreased significantly, which, of course, hinders the renovation and reequipment of the material and technical base of production, and, consequently, the increase in the competitiveness of national products.

However, the import structure reflects the level of competitiveness of certain sectors of the national industry: the lower it is, the larger the presence of imported goods on the domestic market of the Stavropol Territory is.

Too fast growth of import means increased risks for the exchange rate. The growing import costs reduce the net inflow of foreign exchange income from foreign trade, i.e. decrease the surplus from foreign transactions. A rapid growth in import is also a risk factor for the capital flow [6].

The threats to economic security in foreign trade associated with entering the World Trade Organization increase. When joining the WTO, Russia has to accept a favoring regime in the foreign trade. 
WTO member countries insist on reducing the import duty down to $11 \%$, while the current tariff is $20 \%$.

For agricultural products, the average rate will decrease down to $18 \%$, for industrial goods - down to $7.6 \%$, and further down to $5 \%$, which will contribute to the bursting rush of import.

Thus, according to the analysis of threats to the economic security of the Stavropol Territory in foreign trade, it is possible to state that the region has the minimal internal sustainability. As a result, almost all risk factors can create critical situations. Risk management supposes the foreknowledge of possible critical situations in order to prevent, mitigate and weaken the expected situations.

Now the main countermeasures to the threats to economic security both in the Stavropol Territory and in Russia, as a whole, include the use of the protectionism and free trade policies.

Developing national economies must take protective measures because here it is necessary to protect economic sectors that emerge and are formed under the impact of the scientific and technological progress, as well as to protect them from competitive efficient and foreign enterprises that have been operating on the world market for a long time.

There are arguments stated by opponents of the protective policy. It is possible to specify the following ones:

1. Illogicality of the protective policy that aims at achieving a positive trade balance and restraining import operations. This causes the reduction of the volume of export operations as a result of analogous reactions with international partners, and leads to trade imbalance rather than positive balance,

2. Areas of the national economy protected by its barriers lose the incentive for innovation, because competition from the world market decreases,

3. The multiplier effect of protectionism: the technological interconnection among industries leads to the fact that if the protection is introduced for some branches of the technological chain, it will be also required by technologically related industries,

4. Protectionism can damage economic interests of consumers who have to pay both for the imported goods clapped with duties and for nationally produced goods, and

5. Advantages of the international specialization are not used optimally, because restrictions are imposed on imported cheap goods. In addition to the policy of protectionism, a free trade policy emerges in equal relative proportions. Free trade is a policy of noninterference of the state in international trade (free trade) that develops in accordance with the international division of labor and modern versions of the theory of comparative advantages. Positive aspects in favor of free trade are considered to be critical aspects of protectionism.

The advantages of free trade are as follows:

- Competition processes both among national producers and on the world market in general are stimulated,

- International trade is conducted in accordance with the law of comparative competitive advantages,

- Opportunities are created for the use of the international specialization that is considered to be the basis of growth for producers and consumers, and

- It contributes to the market expansion: it creates the basis for mass production and a positive effect from it.

Followers of free trade believe that the arguments in favor of protectionism are controversial, because the goals it sets can be achieved with lower costs.

In order to manage the economic security in the foreign trade, it is necessary to create a mechanism to counteract threats to the economic security based on a combination of organizational structures, methods, ways and techniques, as well as legal norms used to achieve satisfaction of interests of the state or its subjects with the foreign trade economic activity that is stable to external and internal threats and guarantees the growth of the level and quality of life of its citizens.

The creation of an efficient mechanism to counteract threats to the economic security in foreign trade activities should be based on the following stages:
1. To define interests of the foreign economic security arising and changing under the impact of various threats.

2. To define threats, parameters of the foreign economic security, their threshold values.

3. To monitor values of the foreign economic security.

4. To develop a strategy for the foreign economic security of the region based on certain goals and tasks of the foreign economic security.

5. To develop legal norms of the foreign economic security.

6. To establish organizational structures and give them responsibilities and powers.

7. To evaluate the efficiency of state policy in the area of foreign economic security.

It is important for the country and its regions to use positive experience of the EU countries, the United States and Japan based on adequate indicators of assessing threats to foreign economic security, to adopt standard regulations, and to define directions of the state policy.

Now in Russia there are no concept and strategy of the foreign economic security, except for the basic document "The National Security Strategy of the Russian Federation until 2020" that specifies the following threats to economic security in foreign trade:

- Further improvement of the production and export structure, antimonopoly regulation and support of competition policy,

- Considerable strengthening of financial markets and increase in the liquidity of the banking system,

- Development of a national innovation system to implement highperformance projects and top priority programs on developing high-technology sectors of the economy,

- Formation of a system of scientific and technological forecasting and implementation of scientific and technological priorities, strengthening the integration of science, education and production, - Development of the industry of information and telecommunication technologies, computer facilities, radio electronics, telecommunication equipment and software, and

- Development of new resources, modernization of top priority sectors of the national economy.

In the previously approved "Concept of Economic Security of the Russian Federation until 2020", the concept of long-term socioeconomic development of the Russian Federation, it is possible to read the statement that the implementation of top priority areas of the foreign economic policy supposes its further development and strengthening in the system of regulatory legal acts that also include:

- Priorities of customs and tariff policy,

- Programs contributing to export activities, and

- Plans for trade and economic cooperation with foreign states.

None of these documents has been developed and adopted by now. These normative acts mainly take into account the pricing factors of supporting the national commodity producer. According to the world practice, the lower the impact of a firm on the market is, the less it can prevent price adjustment, and, therefore, the simpler pricing system it should use. Modern conditions of the foreign trade market development suggest the search for unaccounted price formation elements that, although subjectively, will be able to most accurately substantiate the value of goods. Most foreign trade companies have individual features of their products with a high degree of competitiveness [7].

According to the above mechanism that counteracts negative factors, and the emergence of threats in foreign economic activities, it is necessary to develop legal regulation instruments:

1. To develop a concept for ensuring the foreign economic security both for the Russian Federation and its regions that includes such provisions as the liberalization of export operations by using protective regulation and the transfer of operational decisions to regions; exceeding growth tempos of services export as compared to goods export; creating a system of legal regulation of export and import operations, etc.

2. To regulate the relations of Russia and its regions with foreign states in the area of foreign economic activity and to determine the 
implementation regime taking into account the contribution to its development and ensuring the economic security.

3 . To comprehensively organize ensuring the foreign economic activity based on competent bodies of ensuring foreign economic security of the state, a clear regulatory procedure of providing the foreign economic activity taking into account peculiarities of export and import of certain types of goods and services, registration of exporters of strategically important commodities, volumes of export and import for state needs.

4. To improve the mechanism of regulating the foreign economic activity in order to ensure security in the foreign economic area: to regulate customs, licensing and export and import quoting issues in details, etc.

5. To carry out control actions in the foreign economic activity on using the liability for violating the legislation on the foreign economic activity.

In addition, in the country and its regions it is necessary to continue taking the following measures to support the national export:

- To provide export support (guarantee support, state guarantees of political and long-term commercial risks for export operations),

- To reimburse a part of interest rates on export loans, to use longterm export crediting,

- To use services of the Development Bank,

- To develop the state support of the exhibition and fair activities in the Russian Federation,

- To carry out information and consulting support of exporters,

- To introduce target tariff preferences,

- To create favorable terms and conditions for the trade development in the common economic space, the CIS and the SCO, and

- To take measures aimed at extending the access of Russian exporters to foreign markets [8].

All above measures, even as recognized by the management, are used inefficiently and are based on the complexity of procedures, excessive requirements for exporters, lack of state financial security, etc.

\section{Conclusion}

Taking into account the problems related to regulating foreign trade relations, the creation of efficient support for the Russian export potential has become a prerequisite for ensuring the economic security of the state. Firstly, there are no criteria that would make it possible to assess the efficiency of state programs to support export. The movement of funds under programs on supporting export by types of costs, commodity groups, economic sectors and partner countries is not considered to be transparent. Secondly, special attention should be paid to the creation of a specialized executive body in the area of foreign trade policy. Thirdly, it is necessary to form a full-fledged financial institution on crediting export, which would be able to attract financing from external sources. Fourthly, it is necessary to simplify and transform procedures for issuing export licenses, to reduce VAT refunds for exporters, and to review the high duties for imported equipment and raw materials that are deficient.

Thus, it is necessary to note that the insufficient efficiency of the current mechanism for ensuring economic security in foreign trade activities is related to the lack of clear legal and administrative norms. On the regional level, the issues related to foreign economic security in the foreign trade are very poorly touched on. The resolution of the above problems should become a part of the National Security Strategy of the Russian Federation, or other legislative acts detailing the economic growth of the country and its regions.

\section{References}

[1] G.I. Panaedova, N.V. Maslennikova, S.M. Gorlov, Indikativnaya model razvitiya Severo-Kavkazskogo makroregiona [Indicative model of developing the North Caucasian macroregion], Bulletin of Tomsk State University, Economy 39 (2017) 54-70.

[2] Usloviya dlya vedeniya biznesa v Rossii (rejting Doing Business) [Conditions for doing business in Russia (Doing Business rating)]. DagLife. https://dag.life/2017/04/01/usloviya-dlya-vedeniyabiznesa-v-rossii-rejting-doing-business/. Revised April 1, 2017. Accessed July 6, 2018.

[3] M.A. Sirotinina, Klassifikatsiya ugroz ekonomicheskoy bezopasnosti Rossii vo vneshnetorgovoy sfere [Classification of threats to Russian economic security in foreign trading], Moscow, 2011.

[4] Official site of the Stavropol region. http://www.stavregion.ru. Accessed July 6, 2018.

[5] L.I. Ushvitskiy, T.A. Kulagovskaya, A.A. Ter-Grigor'yants, I.V. Solovyeva, A.A. Babich, The use of multivariate statistical analysis methods in the process of tangible assets assortment optimization, Indian Journal of Science and Technology 9(16) (2016) 89896.

[6] L.I. Ushvitskii, T.A. Kulagovskaya, A.A. Ter-Grigor'yants, I.V. Solovyova, E.S. Mezentseva, Methodological tools for risk assessment in industrial enterprises, International Journal of Economics and Financial Issues 5(4) (2015) 1011-1016.

[7] A.V. Kravchenko, N.V. Maslennikova, M.G. Rusetskiy, E.N. Kovtun, A.A. Orazaliev, Factor combination of the price for the foreign trade contract and its influence on the international pricing, International Journal of Economic Perspectives 11(2) (2017) 337-344.

[8] N.V. Maslennikova, E.N. Kovtun, Sozdaniye mekhanizma effektivnogo protivodeystviya ugrozam vneshneekonomicheskoy bezopasnosti regiona [Creation of a mechanism for effective counteraction to threats to the external economic safety of the region], Economics and Management: Problems, Solutions, 2(4) (2016) 215-221 